\title{
Mortality of farmers and farmers' wives in England and Wales 1979-80, 1982-90
}

\author{
Hazel Inskip, David Coggon, Paul Winter, Brian Pannett
}

\begin{abstract}
Objectives-To examine the mortality patterns of male and female farmers and farmers' wives in England and Wales.

Methods-Information on all deaths in England and Wales at ages 20-74 during the periods $1979-80$ and $1982-90$ was obtained from the Office of Population Censuses and Surveys. Proportional mortality ratios (PMRs) and proportional cancer mortality ratios (PCMRs) were used to compare the mortality of farmers with that of the general working population, and of farmers' wives with wives of all working men.

Results-Farmers and farmers' wives had high mortality from accidents and suicide and from certain respiratory diseases. Mortality from hernia was also raised. Deaths from cancer were generally below expectations, but the PMR for prostatic cancer was $112(95 \%$ CI 106-118). The PMRs and PCMRs for oesophageal cancer were significantly increased in male farmers from two counties where cider is produced.

Conclusions-The occupational hazards of farming continue to be associated with excess mortality, and most of the risks extend also to farmers' wives. Action is needed to reduce deaths, particularly from accidents and suicide.
\end{abstract}

(Occup Environ Med 1996;53:730-735)

Epidemiology Unit,

University of

Southampton,

Southampton Genera

Hospital,

Southampton

H Inskip

D Coggon

$P$ Winter

B Pannett

Correspondence to:

Hazel Inskip, MRC

Environmental Epidemiolog

Unit, University of

Southampton, Southampton

Southampton, South

Southampton SO16 6YD.

Accepted 11 July 1996 have higher than average exposure to solar radiation. In addition, many farmers have to cope with financial insecurity and associated stress.

Farmers are not, however, an easy group to study, as they are widely scattered in relatively small businesses. Much of the information about the risks that they face has come from routine analyses of death certificates and cancer registrations. ${ }^{1-12}$ These have been supplemented by a few cohort studies $^{13-16}$ and case-control and cross sectional studies of selected disorders. ${ }^{17-26}$ Such studies have, in general, found that farmers are at increased risk of suicide and many types of accidents, diabetes, respiratory diseases, and certain cancers. In England and Wales, routine analyses of occupational mortality have been conducted for three or five year periods around census years and have generally focused on deaths in men..$^{1-4}$ We report an analysis of deaths in England and Wales over a longer period of 11 years from $1979-80$ and 1982-90 which looks not only at male farmers, but also at women working in agriculture and farmers' wives.

\section{Methods}

The Office of Population Censuses and Surveys (OPCS) provided us with information on all deaths at ages $20-74$ in England and Wales during the years $1979-80$ and 1982-90. Data for 1981 were omitted because industrial action in that year by registrars of deaths made them unreliable. Table 1 shows the information provided. Causes of death were coded to the ninth revision of the international classification of diseases (ICD). ${ }^{27}$ The occupations recorded on the certificates were coded with the OPCS 1980 classification of occupations ${ }^{28}$ and those in farming, horticulture, and gardening (codes 040, 076.01, 076.02, 076.03, 076.04, 076.06, 077, 078.01, 078.02, 079, and 083) were singled out for analysis.

Proportional mortality ratios (PMRs) were calculated for each cause of death, with fiveyear age, sex, and social class specific proportions in all occupations combined for the whole of England and Wales providing the standard. For analyses of male and female farmers, the standard comprised all deaths for which an occupation had been recorded on the certificate. For farmers' wives the standard was all deaths in married women whose husbands' occupations had been recorded. Confidence intervals (CIs) for PMRs were derived by the method described by Breslow
The last full time occupation is only recorded on a woman's death certificate if she has been in

full time employment for most of her potential working life. Table 1 Information pron

\begin{tabular}{llll}
\hline Type of information & Men & Women & Married women and widows \\
\hline Occupation & Last full time & Last full time* & Husband's most recent \\
& Yes & Yes & full time \\
Age at death & Yes & Yes & Yes \\
Underlying cause of death & Yes & Of husband \\
Employment status & Yes & Yes & No
\end{tabular}


and Day ${ }^{29}$ and by regarding the observed number of deaths as a Poisson variable. The full age range of 20-74 years was used in all analyses. Elsewhere, analyses of accidental and violent deaths of the same data were restricted to preretirement ages, ${ }^{5}$ but as farmers do not necessarily retire at the conventional age, deaths up to age 74 have been considered here. For cancer mortality, proportional cancer mortality ratios (PCMRs) were also calculated from all deaths from cancer in place of deaths from all causes in the denominator of the proportions.

\section{Results}

Over the 11 year period of study 60268 deaths at ages 20-74 were recorded in male farmers, 2512 in female farmers, and 35222 in wives of farmers. Thirty per cent of the female farmers were also recorded as being wives of farmers, so the analyses of female farmers and farmers' wives are not independent of each other.

Table 2 shows the PMRs and PCMRs for major causes of death. Deaths from neoplasms, and circulatory, respiratory, and digestive disorders were below or close to those expected. Increased PMRs for endocrine, nutritional, and metabolic diseases were explained by excesses of diabetes. Mortalities from disorders of the nervous system, musculoskeletal disorders, and accidents, poisonings, and violence were also above the average for England and Wales.

ACCIDENTS, POISONINGS, AND VIOLENCE

Table 3 shows PMRs for the major cause groupings of accidental and violent death and for specific causes that were associated with

Table 2 Mortality from major causes of death in farmers aged 20-74 in England and Wales, 1979-80 and 1982-90

\begin{tabular}{|c|c|c|c|c|c|c|}
\hline \multirow[b]{2}{*}{ Cause of death (ICD) } & \multicolumn{2}{|c|}{ Male farmers } & \multicolumn{2}{|c|}{ Female farmers } & \multicolumn{2}{|c|}{ Farmers' wives } \\
\hline & Deaths & $\operatorname{PMR}(95 \% \mathrm{CI})$ & Deaths & PMR (95\% CI) & Deaths & $P M R(95 \% C I)$ \\
\hline Infectious and parasitic diseases (001-139) & 230 & $94(82-107)$ & 3 & $27(5-78)$ & 154 & $105(89-123)$ \\
\hline Neoplasms (140-239): & 17182 & $95(93-96)$ & 1025 & $100(94-107)$ & 12618 & $95(94-97)$ \\
\hline All malignant neoplasms (140-208) & 17007 & $94(92-95)$ & 1018 & $100(94-106)$ & 12471 & $94(93-96)$ \\
\hline \multicolumn{7}{|l|}{ Endocrine, nutritional, and metabolic } \\
\hline diseases $(240-279)$ : & 803 & $111(103-119)$ & 44 & $116(84-155)$ & 855 & $139(130-148)$ \\
\hline Diabetes mellitus (250) & 672 & $119(110-128)$ & 32 & $114(78-161)$ & 685 & $144(133-155)$ \\
\hline Mental disorders $(290-319)$ & 299 & $103(91-115)$ & 24 & $127(81-189)$ & 220 & $92(80-105)$ \\
\hline Diseases of the circulatory system $(390-459)$ : & 29929 & $101(100-102)$ & 945 & $98(92-104)$ & 15565 & $104(102-106)$ \\
\hline Ischaemic heart disease $(410-414)$ & 20478 & $97(96-99)$ & 495 & $92(84-100)$ & 8559 & $99(97-102)$ \\
\hline Cerebrovascular disease $(430-438)$ & 5210 & $113(110-116)$ & 266 & $104(92-117)$ & 4289 & $112(109-115)$ \\
\hline Diseases of the respiratory system $(460-519)$ : & 5184 & $96(93-99)$ & 152 & $88(74-103)$ & 2310 & $89(85-92)$ \\
\hline Chronic bronchitis and emphysema $(491-2,496)$ & 2879 & $90(86-93)$ & 54 & $72(54-93)$ & 823 & $73(68-78)$ \\
\hline Diseases of the digestive system $(520-579)$ & 1291 & $86(82-91)$ & 74 & $93(73-117)$ & 1094 & $96(90-102)$ \\
\hline $\begin{array}{l}\text { Diseases of the genitourinary system }(580-629) \\
\text { Diseases of musculoskeletal system and }\end{array}$ & 550 & $118(109-129)$ & 20 & $89(54-137)$ & 380 & $112(101-124)$ \\
\hline \multicolumn{5}{|l|}{ Diseases of musculoskeletal system and } & & \\
\hline Accidents, poisonings, and violence (800-999) & 3307 & $129(125-134)$ & 143 & $143(121-169)$ & 831 & $105(98-112)$ \\
\hline Other causes $(280-9,630-709,740-799)$ & 326 & $107(96-119)$ & 15 & $71(40-117)$ & 233 & $103(90-117)$ \\
\hline
\end{tabular}

Table 3 Mortality from accidents, poisoning, and violence in farmers aged 20-74 in England and Wales, 1979-80 and 1982-90. (The causes of death presented are the major relevant subgroups of accidents, and specific types for which the PMR was significantly raised (P $<0.05)$ in at least one group and based on $\geqslant 3$ deaths)

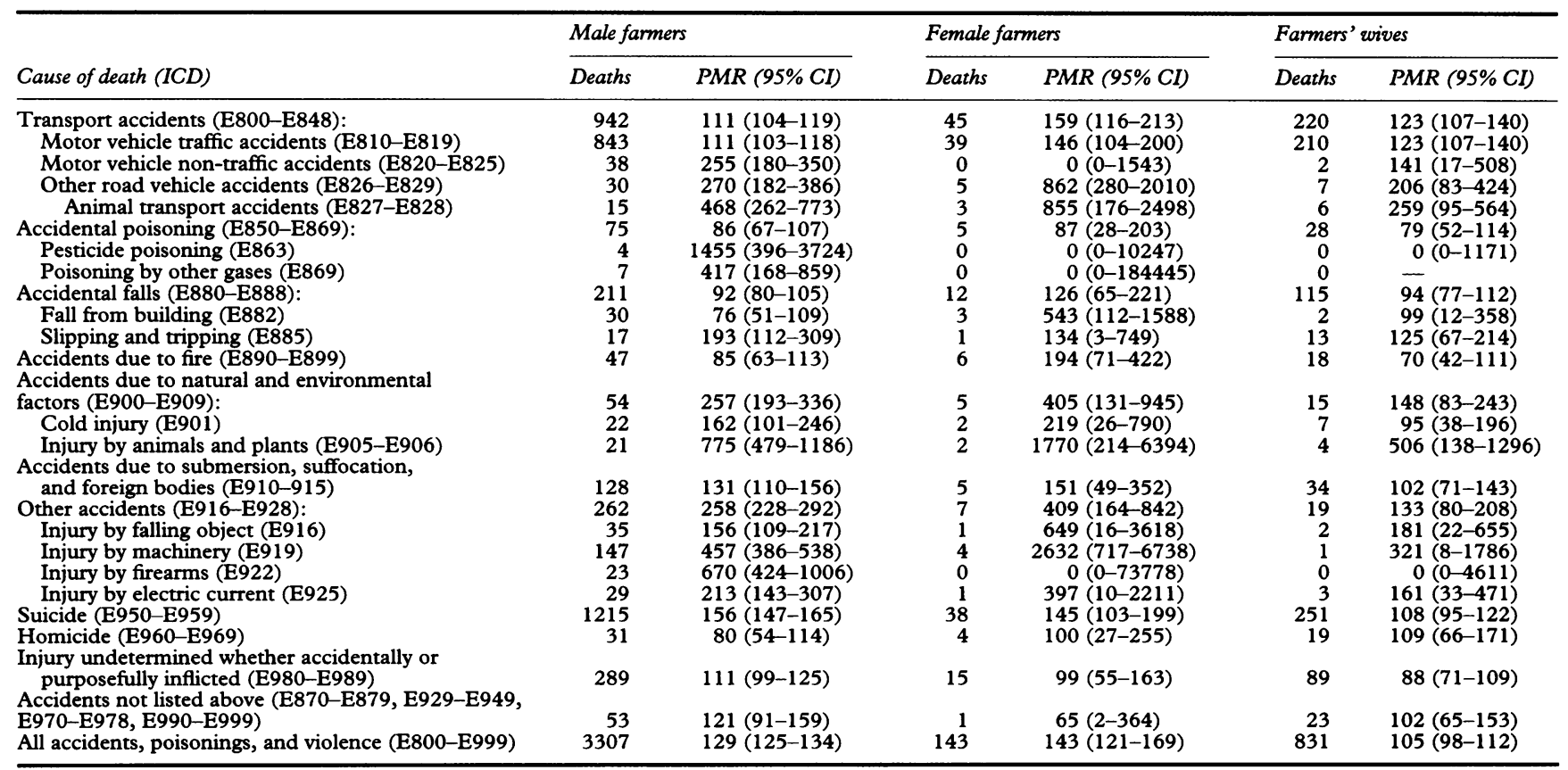


significantly raised PMRs $(P<0.05)$ in one or more of the three groups studied. It is apparent that both male and female farmers and those recorded as farmers' wives were at increased risk of various types of accidental death, and striking excesses in all three groups were found for deaths from injury by animals and plants. In men, there was a more than fourfold excess of deaths from injury by machinery, based on 147 deaths, and an excess was also apparent for women, although the number of deaths was small. Male farmers also had increased mortality from pesticide poisoning (PMR 1455 based on four deaths) and injury by firearms (PMR 670, 23 deaths), but no deaths from these causes occurred in women. The number of suicides was about $50 \%$ greater than expected in both male and female farmers, but the excess was less evident in farmers' wives.

When self employed farmers were considered separately, the excesses of deaths from injury and poisoning and from suicide were even greater than for all farmers. Table 4 shows the PMRs for self employed male farmers and their wives, but the numbers of deaths in self employed female farmers were too small for meaningful analysis. For almost every cause listed, including suicide, the PMR for self employed male farmers was greater than that for all male farmers. Among the wives of self employed farmers, deaths from most types of injury were few, but the PMR for suicide was higher than in farmers' wives overall.

HERNIA

Mortality from both inguinal and other hernia was significantly increased in male farmers (table 5). Inguinal hernia is rarer in women, but female farmers and farmers' wives had excesses of deaths from other forms of hernia.

LUNG CANCER AND RESPIRATORY DISEASES

Table 6 shows the PMRs for lung cancer and selected respiratory diseases. The excesses of farmers' lung disease are not surprising in this group, although in previous occupational mortality analyses deaths from this cause have not been noted in women. Only one of the women who died from this cause was both a farmer in her own right and the wife of a farmer. Excesses were also found for other and unspecified allergic pneumonitis, which may include misdiagnosed cases of farmers' lung disease. A geographical analysis of farmers' lung disease in men showed that farmers in the north and west of the country were at greatest risk, the PMRs ranging from 141 in the Anglia

Table 4 Mortality from accidents, poisoning, and violence in self employed farmers and their wives at ages 20-74 in England and Wales, 1979-80 and 1982-90

\begin{tabular}{|c|c|c|c|c|}
\hline \multirow[b]{2}{*}{ Cause of death (ICD) } & \multicolumn{2}{|c|}{ Self employed male farmers } & \multicolumn{2}{|c|}{ Wives of self employed farmers } \\
\hline & Deaths & $\operatorname{PMR}(95 \% \mathrm{CI})$ & Deaths & $\operatorname{PMR}(95 \% C I)$ \\
\hline $\begin{array}{l}\text { Motor vehicle traffic accidents (E810-E819) } \\
\text { Off road motor vehicle accidents (E820-E825) } \\
\text { Animal transport accidents (E827-E828) } \\
\text { Pesticide poisoning (E863) } \\
\text { Poisoning by other gases (E869) } \\
\text { Fall from building (E882) } \\
\text { Slipping and tripping (E885) } \\
\text { Cold injury (E901) } \\
\text { Injury by animals and plants (E905-E906) } \\
\text { Injury by falling object (E916) } \\
\text { Injury by machinery (E919) } \\
\text { Injury by firearms (E922) } \\
\text { Injury by electric current (E925) } \\
\text { Suicide (E950-E959) }\end{array}$ & $\begin{array}{r}259 \\
15 \\
10 \\
2 \\
5 \\
16 \\
7 \\
7 \\
10 \\
14 \\
89 \\
17 \\
15 \\
546\end{array}$ & $\begin{array}{l}114(101-129) \\
368(206-607) \\
446(214-820) \\
1299(157-4691) \\
661(215-1543) \\
200(114-325) \\
184(74-378) \\
211(85-435) \\
869(417-1598) \\
286(156-480) \\
1045(839-1286) \\
867(505-1389) \\
355(199-585) \\
196(180-213)\end{array}$ & $\begin{array}{r}101 \\
0 \\
4 \\
0 \\
0 \\
1 \\
4 \\
2 \\
2 \\
2 \\
0 \\
0 \\
2 \\
147\end{array}$ & $\begin{array}{l}136(111-165) \\
0(0-414) \\
284(77-728) \\
0(0-1901) \\
\frac{1}{134}(3-747) \\
103(28-264) \\
76(9-274) \\
359(43-1297) \\
272(33-982) \\
0(0-2598) \\
0(0-36889) \\
256(31-925) \\
127(107-149)\end{array}$ \\
\hline All accidents, poisonings, and violence (E800-E999) & 1309 & $162(153-171)$ & 417 & $118(107-130)$ \\
\hline
\end{tabular}

Table 5 Mortality from hernia in farmers aged 20-74 in England and Wales, 1979-80 and 1982-90

\begin{tabular}{|c|c|c|c|c|}
\hline & \multicolumn{2}{|c|}{ Inguinal hernia (ICD 550) } & \multicolumn{2}{|c|}{ Other hernias (ICD 551-553) } \\
\hline & Deaths & $P M R(95 \% C I)$ & Deaths & $P M R(95 \% C I)$ \\
\hline $\begin{array}{l}\text { Male farmers: } \\
\text { Self employed male farmers } \\
\text { Female farmers } \\
\text { Farmers' wives } \\
\text { Wives of self employed farmers }\end{array}$ & $\begin{array}{r}41 \\
17 \\
0 \\
1 \\
0\end{array}$ & $\begin{array}{c}191(137-259) \\
243(142-390) \\
0(0-1276) \\
29(1-162) \\
0(0-243)\end{array}$ & $\begin{array}{r}41 \\
16 \\
5 \\
53 \\
21\end{array}$ & $\begin{array}{l}149(107-202) \\
143(82-232) \\
205(67-478) \\
138(104-181) \\
151(94-232)\end{array}$ \\
\hline
\end{tabular}

Table 6 Mortality from lung cancer and selected respiratory disorders at ages 20-74 in farmers in England and Wales, 1979-80 and 1982-90

\begin{tabular}{|c|c|c|c|c|c|c|}
\hline \multirow[b]{2}{*}{ Cause of death (ICD) } & \multicolumn{2}{|c|}{ Male farmers } & \multicolumn{2}{|c|}{ Female farmers } & \multicolumn{2}{|c|}{ Farmers' wives } \\
\hline & Deaths & $P M R(95 \% C I)$ & Deaths & $P M R(95 \% C I)$ & Deaths & $P M R(95 \% C I)$ \\
\hline $\begin{array}{l}\text { Lung cancer }(162) \\
\text { Influenza }(487) \\
\text { Chronic bronchitis and emphysema }(491,492,496) \\
\text { Farmers' lung disease }(495 \cdot 0) \\
\text { Other and unspecified allergic pneumonitis }\end{array}$ & $\begin{array}{r}5930 \\
46 \\
2879 \\
56\end{array}$ & $\begin{array}{c}88(86-91) \\
163(120-218) \\
90(86-93) \\
1089(823-1416)\end{array}$ & $\begin{array}{r}167 \\
3 \\
54 \\
2\end{array}$ & $\begin{array}{c}92(78-107) \\
175(36-511) \\
72(54-93) \\
7692(932-27787)\end{array}$ & $\begin{array}{r}1867 \\
36 \\
823 \\
6\end{array}$ & $\begin{array}{c}81(78-85) \\
155(109-215) \\
73(68-78) \\
862(316-1876)\end{array}$ \\
\hline$(495 \cdot 1-495 \cdot 9)$ & 8 & $548(237-1080)$ & 0 & $0(0-12296)$ & 2 & $253(31-915)$ \\
\hline
\end{tabular}


Table 7 Proportional cancer mortality ratios for major cancer sites in farmers aged 20-74 in England and Wales, 1979-80 and 1982-90

\begin{tabular}{|c|c|c|c|c|c|c|}
\hline \multirow[b]{2}{*}{ Cancer site (ICD) } & \multicolumn{2}{|c|}{ Male farmers } & \multicolumn{2}{|c|}{ Female farmers } & \multicolumn{2}{|c|}{ Farmers' wives } \\
\hline & Deaths & PCMR (95\% CI) & Deaths & PCMR $(95 \% C I)$ & Deaths & PCMR $(95 \%$ CI) \\
\hline Oral cavity and pharynx (141-148) & 213 & $93(81-106)$ & 11 & $120(60-215)$ & 112 & $100(83-121)$ \\
\hline Oesophagus (150) & 734 & $113(105-121)$ & 30 & $125(85-179)$ & 291 & $99(88-111)$ \\
\hline Stomach (15i) & 1433 & $103(98-108)$ & 41 & $92(66-125)$ & 565 & $96(89-105)$ \\
\hline Colon (153) & 1191 & $106(100-112)$ & 74 & $98(77-124)$ & 1104 & $111(105-118)$ \\
\hline Rectum (154) & 764 & $102(95-109)$ & 37 & $114(80-157)$ & 465 & $106(97-117)$ \\
\hline Liver (155) & 125 & $69(57-82)$ & 6 & $77(28-168)$ & 80 & $91(72-113)$ \\
\hline Gall bladder (156) & 58 & $72(54-93)$ & 6 & $76(28-165)$ & 134 & $126(106-150)$ \\
\hline Pancreas (157) & 767 & $101(94-108)$ & 41 & $97(69-131)$ & 504 & $93(85-102)$ \\
\hline Larynx (161) & 125 & $77(64-92)$ & 0 & $0(0-132)$ & 32 & $89(61-125)$ \\
\hline Trachea, bronchus, and lung (162) & 5930 & $93(91-96)$ & 167 & $90(77-104)$ & 1867 & $85(81-89)$ \\
\hline Soft tissue (171) & 67 & $102(79-130)$ & 2 & $49(6-176)$ & 53 & $121(91-158)$ \\
\hline Melanoma of skin (172) & 118 & $94(78-113)$ & 10 & $101(48-185)$ & 111 & $96(79-115)$ \\
\hline Other skin (173) & 54 & $127(95-166)$ & 7 & $422(170-870)$ & 32 & $154(105-217)$ \\
\hline Female breast (174) & - & - & 194 & $84(73-97)$ & 2765 & $98(95-102)$ \\
\hline Uterus, part unspecified (179) & - & - & 5 & $102(33-237)$ & 93 & $134(108-164)$ \\
\hline Cervix (180) & - & - & 44 & $111(81-149)$ & 392 & $93(84-103)$ \\
\hline Body of uterus (182) & - & - & 22 & $126(79-191)$ & 281 & $133(118-149)$ \\
\hline Ovary (183) & - & - & 94 & $122(98-149)$ & 930 & $104(98-111)$ \\
\hline Prostate (185) & 1361 & $121(115-128)$ & - & - & & - \\
\hline Bladder and urinary organs $(188,189 \cdot 1-189 \cdot 8)$ & 598 & $91(84-99)$ & 13 & $76(40-130)$ & 188 & $89(77-103)$ \\
\hline Kidney, except pelvis $(189.0)$ & 305 & $89(79-100)$ & 7 & $57(23-117)$ & 162 & $103(88-121)$ \\
\hline Brain (191) & 469 & $112(102-122)$ & 26 & $108(71-159)$ & 285 & $103(91-116)$ \\
\hline Thyroid (193) & 22 & $79(49-120)$ & 7 & $213(86-440)$ & 70 & $156(122-197)$ \\
\hline Non-Hodgkin's lymphoma $(200,202)$ & 449 & $114(104-125)$ & 30 & $143(96-204)$ & 294 & $112(100-126)$ \\
\hline Hodgkin's disease (201) & 86 & $103(83-128)$ & 5 & $138(45-231)$ & 40 & $105(75-143)$ \\
\hline Myeloma (203) & 272 & $117(104-132)$ & 19 & $138(83-216)$ & 187 & $106(91-122)$ \\
\hline Leukaemia (204-208) & 469 & $114(104-125)$ & 25 & $116(75-172)$ & 304 & $112(100-125)$ \\
\hline
\end{tabular}

region to over 2000 in north east England and in Wales. ${ }^{5}$ Mortality from influenza was raised in all three groups although the number of female farmers dying from this cause was small. The excess of deaths from influenza was predominantly in the older age groups, with a PMR of 188 at ages 65-74 in men based on 38 deaths (95\%CI 133-258). Deficits of lung cancer and chronic bronchitis and emphysema were found in all three groups.

\section{OTHER CANCERS}

In contrast to the excesses noted above, there were few excesses of cancers in either farmers or their wives. The PMRs for all cancers combined were less than or equal to 100 in all three groups analysed. For specific types of cancer, the only significant excess in men was for prostatic cancer with a PMR of 112 based on 1361 deaths (95\% CI 106-118).

Table 7 shows PCMRs for all cancer sites with more than 50 deaths in at least one of the groups. The PCMRs for non-melanomatous cancer of the skin, brain cancer, nonHodgkin's lymphoma, myeloma, and leukaemia were increased in all three groups, and significantly so in at least one of the groups.

It was also possible to perform geographical analyses for some cancers in male farmers. As noted elsewhere, ${ }^{5}$ mortality from melanoma, although not increased overall, showed a geographical gradient, with the highest PMRs and PCMRs being found in the southern regions, particularly the south west (PMR 164, 95\%CI 94-266, PCMR 186, 95\%CI 106-131, 16 deaths) and Anglia (PMR 143, 95\%CI 91-215, PCMR 139, 95\%CI 88-210, 23 deaths). By contrast, mortality from other cancer of the skin showed no association with latitude. A tendency for higher PMRs and PCMRs in the south than in the north was found for non-Hodgkin's lymphoma and for prostatic cancer, which was increased overall in male farmers, but there was no apparent link with agricultural practices or herbicide use by region. ${ }^{5}$ Whether analysed with PMRs or PCMRs, significant excesses of oesophageal cancer were found for two major cider producing counties-namely, Hereford and Worcester (PMR 175, 95\%CI 122-242, PCMR 167, 95\%CI 117-231, 36 deaths) and Somerset (PMR 156, 95\%CI 98-234, PCMR 159, 95\%CI 101-240, 23 deaths).

\section{Discussion}

This is the largest analysis of mortality in farmers that has ever been carried out in Britain. As such, it provides information about rarer causes of death, such as influenza and hernia, that could not normally be studied, and about patterns of mortality in female farmers as well as in men. Historically, there has been little research into the risks faced by women in agriculture, often because of doubt about the reliability of population denominators for the death rates and because few women are classified as farmers in their own right. ${ }^{30}$ Recently they have started to receive greater attention, ${ }^{16} 3132$ although the focus has been mainly on cancer. We have examined both those classified as farmers themselves and also farmers' wives. Whereas there was some overlap between these categories, it was not substantial

Against the advantage of the study's size must be set several limitations. As an analysis of mortality it could be used to look only at fatal hazards. Moreover, it was subject to the biases that arise from inaccurate certification of causes of death. In general, these would be expected to obscure occupational associations rather than spuriously to inflate risks.

Information about work was restricted to the subject's last full time occupation, or in the case of farmers' wives, that of her husband. Some occupational hazards do not lead to death until many years after first exposure, by which time the victim may have changed job. 
Again, however, the effect would normally be to obscure associations and bias risk estimates towards the null.

Another limitation was the use of PMRs rather than death rates. This was necessary because appropriate population denominators were not available, but it complicates interpretation because of the low overall mortality of farmers in England and Wales. In an analysis for the years 1979-80 and 1982-3, the standardised mortality ratio for all causes of death combined in male farmers, defined as in our study, was 87 compared wiht the national population. ${ }^{4}$ It follows that the PMRs presented are likely to exaggerate risks somewhat. Nevertheless, useful conclusions can be drawn.

Farmers in many countries have long been recognised as being at increased risk of accidents, ${ }^{1-7} 1112{ }^{33}$ although, as noted elsewhere, ${ }^{34}$ Scandinavian countries are an exception to the rule. ${ }^{13}{ }^{14}$ In England and Wales, the types of accident to which farmers are prone have not been examined in detail, although studies from elsewhere indicate that machinery, off road vehicle accidents, falls, and animals are major contributors to injuries and fatalities in farm workers. ${ }^{11335-37}$ Similarly, we found that injury by machinery and off road motor vehicle accidents accounted for much of the excess of non-traffic accidents in male farmers. For women, injuries by animals and in animal transport accidents were the major contributors to excess fatalities, although the number of accidental deaths was far smaller than for men. The difference may reflect the varieties of work performed by men and women on farms, and indeed risks do vary across different types of farming activities, with those involved in dairy farming seeming to have the most. ${ }^{35-37}$

Mortality from accidents was particularly high among self employed farmers. Farmers, and especially those who are self employed, work in small businesses, which generally have higher rates of accidents than larger firms. ${ }^{38}$ In Finnish farmers, mortality from various causes including accidents was found to be inversely related to size of farm. ${ }^{13}$ Targeting preventive strategies at the self employed and small businesses is not easy, but offers the most scope for improvement in the unacceptably high rate of fatal accidents among farmers. Intervention strategies involving education and modification of equipment are being attempted in some farming areas, but surveillance is required to assess their effectiveness. ${ }^{39} 40$

Studies in England and Wales have consistently found high levels of suicide in male farmers. ${ }^{1-341}$ Similarly, rates in North America have tended to be high, ${ }^{11}{ }^{42}$ although exceptions have been identified in Colorado and in Canada. ${ }^{4344}$ Few studies have examined female farmers and when they have the numbers have been small. " A major factor in suicides in farmers is likely to be their ready access to effective means of suicide (pesticides and firearms). Also, financial pressures may contribute to the particularly high rate of suicide in self employed farmers, although a study in Canada found that suicide rates in farmers were independent of economic indicators. ${ }^{44}$

Hernia is a rare cause of death, fatalities occurring from strangulation or complications of surgery. Nevertheless, excess mortality from hernia was clearly apparent in all three groups. It probably reflects the heavy lifting that has been common on farms, particularly in the past. $^{26}$

Farmers' lung disease is a recognised occupational illness. Previous reports of increased mortality from this disease have focused on men, ${ }^{1.4}$ but in our analysis farmers' wives also had an excess. This confirms that at least some of the wives had been exposed to the hazards of farming although it was not recorded as their own occupation on the death certificates. That the excesses were greater in men in the western and northern parts of the country is not surprising, as the wetter climates of those regions promote the growth of the moulds in hay which cause the disease.

The increase of mortality from influenza in farmers was mainly at older ages, and is difficult to explain by any known occupational hazard. Similarly, the high PMRs for diabetes are not readily explained, although excesses in farmers have been noted before.

The slight excesses of certain cancers that were found may be artefacts of proportional mortality analyses. Because cancer mortality was generally low, as is shown by the all cancer PMRs below 100 in each of the three groups, PCMRs are likely to exaggerate the risks even more than PMRs. However, it is noteworthy that the cancers occurring in excess in farmers and farmers' wives-namely, those of the prostate, brain, haematopoietic system, and other skin cancer, have been associated with farming in several other studies. ${ }^{7} 11141722$

The most interesting findings on cancer relate to geographical differences in mortality from melanoma, non-Hodgkin's lymphoma, and oesophageal cancer in male farmers. Although the rates of melanoma in white people are inversely related to latitude, suggesting an effect of solar radiation, the relation between melanoma and exposure to sunlight is complex. Outdoor occupations such as farming do not seem to carry a high risk, and it has been proposed that intermittent exposure to sunlight is most harmful, while regular exposure produces a protective tan. Alternatively, exposure to the sun during childhood may be the major determinant of risk. ${ }^{45}$ In our analysis, farmers did not have a high overall PMR for melanoma but they showed geographical differences in mortality parallel to those in the general population, ${ }^{46}{ }^{47}$ with higher rates in the south. This would be compatible with exposure from the sun during childhood being an important factor.

The PMRs for non-Hodgkin's lymphoma also tended to be higher in the south of the country, consistent with the hypothesis that this malignancy is also related to exposure to sunlight. ${ }^{489}$ Recent data from the United States, however, have not supported this theory. ${ }^{50}$ 
Oesophageal cancer, like melanoma, was not unusually common in farmers overall, although the PCMR in men was increased. However, PMRs and PCMRs were significantly raised in two counties-Hereford and Worcester and Somerset-both of which are notable as centres of cider production. It is possible that the excess results from consumption of rough cider produced on farms. Alcohol is a known cause of oesophageal cancer $^{51}$ and consumption of cider and calvados (another apple based drink) has been associated with a particularly high incidence of the disease in Normandy, France. ${ }^{52}$

In summary, the widespread hazards in agriculture are reflected in increased mortality from several causes of death, both in male and female farmers and in farmers' wives. Particularly pressing is the need to reduce mortality from accidents and suicide.

This analysis was supported by a grant from the Health and Safety Executive and we are grateful to OPCS for providing the data.

1 Registrar General. Decennial supplement, England and Wales, 1951. Occupational mortality. London: HMSO, 1954.

2 Registrar General. Decennial supplement, England and Wales, 1961. Occupational mortality tables. London: HMSO, 1971.

3 Office of Population Censuses and Surveys. Occupational mortality, decennial supplement 1970-2. London: HMSO, 1978.

4 Office of Population Censuses and Surveys. Occupational mortality, decennial supplement 1979-80, 1982-3. London: HMSO, 1986.

5 Office of Population Censuses and Surveys. Occupational health, decennial supplement. London: HMSO, 1995.

6 Instituto superiore per la Prevenzione e la Sicurezza del Lavoro. Mortalità per professioni in Italia negli anni' 80 . Rome: Collana Quaderni ISPESL, 1995.

7 Milham S. Occupational mortality in Washington state, Occupational Safety and Health, 1983 (DHSS (NIOSH) publ No 83-116).

8 Blair A, Malker H, Cantor KP, Burmeister L, Wiklund K. Cancer among farmers. Scand $\mathcal{f}$ Work Environ Health 1985;11:397-407.

9 Blair A, Zahm SH. Cancer among farmers. Occup Med 1991;6:335-54.

10 Blair A, Zahm SH, Pearce NE, Heineman EF, Fraumen $\mathrm{JF}$. Clues to cancer etiology from studies of farmers. Scand $\mathcal{F}$ Work Environ Health 1992;18:209-15.

11 Blair A, Dosemeci M, Heineman EF. Cancer and other causes of death among male and female farmers from twenty-three states. Am F Ind Med 1993;23:729-42.

12 Delzell E, Grufferman S. Mortality among white and nonwhite farmers in North Carolina, 1976-78. Am $\mathcal{f}$ Epidemiol 1985;121:391-402.

13 Notkola VJ, Husman KRH, Laukkanen VJ. Mortality among male farmers in Finland during 1979-83. Scand $\mathcal{F}$ Work Environ Health 1987:13:124-8.

14 Rafnsson V, Gunnarsdóttir $H$. Mortality of farmers in Iceland. Int $\mathcal{f}$ Epidemiol 1989;18:146-51

15 Wigle DT, Semenciw RM, Wilkins K, Riedel D, Ritter L, Morrison HI, Mao Y. Mortality study of Canadian male farm operators: non-Hodgkin's lymphoma mortality and agricultural practices in Sasketchewan. $\mathcal{f}$ Natl Cancer Inst 1990;82:575-82

16 Wiklund $\mathrm{K}$, Dich J. Cancer risks among female workers in Sweden. Cancer Causes Control 1994;5:449-57.

17 Fincham SM, Hanson J, Berkel J. Patterns and risks of cancer in farmers in Alberta. Cancer 1992;69:1276-85.

18 Cantor KP. Farming and mortality from non-Hodgkin's lymphoma: a case-control study. Int $f$ Cancer 1982;29: lymphom $239-47$.

19 Cantor KP, Blair A. Farming and mortality from multiple myeloma: a case-control study with the use of death certificates. F Natl Cancer Inst 1984;72:251-5.

20 Eriksson M, Karlsson M. Occupational and other environmental factors and multiple myeloma: a population based case-control study. Br F Ind Med 1992;49:95-103.
21 Linet MS, Malker HSR, McLaughlin JK, Weiner JA, Blot WJ, Ericsson JLE, Fraumeni JF. Non-Hodgkin's lymphoma and occupation in Sweden: a registry based analysis. Br f Ind Med 1993;50:79-84.

22 van der Gulden JWJ, Kolk J, Verbeek ALM. Prostate cancer and work environment. F Occup Med 1992;34:402-9.

23 Forastiere F, Quercia A, Miceli M, Settimi L, Terenzoni B, Rapiti $\mathrm{E}$ et al. Cancer among farmers in central Italy. Scand $\mathcal{f}$ Work Environ Health 1993;19:382-9.

24 Hoar SK, Blair A, Holmes FF, Boysen CD, Robel RJ Hoover R, Fraumeni JF. Agricultural herbicide use and risk of lymphoma and soft-tissue sarcoma. $\mathfrak{J A M A}$ 1986;256:1141-7.

25 Franceschi S, Barbone F, Bidoli E, Guarneri S, Serraino D, Talamini R, La Vecchia C. Cancer risk in farmers: results from a multi-site case-control study in north-eastern from a multi-site case-control stud

26 Croft P, Coggon D, Cruddas M, Cooper C. Osteoarthritis of the hip: an occupational disease in farmers. $B M \mathcal{F}^{\prime}$ 1992;304: 1269-72.

27 World Health Organisation. International classification of diseases, 9th revision. Geneva: WHO, 1977.

28 Office of Population Censuses and Surveys. Classification of occupations 1980. London: HMSO, 1980.

29 Breslow NE, Day NE. Statistical methods in cancer research. Vol II-The design and analysis of cohort studies. Lyon: International Agency for Research on Cancer, 1987.

30 Engberg L. Women and agricultural work. Occup Med 1993;8:869-82.

31 Alavanja MCR, Akland G, Baird D, Blair A, Bond A, Dosemeci $M$, et al. Cancer and non-cancer risk to women in agriculture and pest control. $\mathcal{F}$ Occup Med 1994;36:1247-50.

$32 \mathrm{McDuffie} \mathrm{HH}$. Women at work; agriculture and pesticides. f Occup Med 1994;36:1240-6.

33 Erlich SM, Driscoll TR, Harrison JE, Frommer MS, Leigh $\mathrm{J}$. Work-related agricultural fatalities in Australia 1982-4. Scand F Work Environ Health 1993;19:162-7.

34 Zwerling C, Burmeister LF, Jensen CM. Injury mortality in Iowa farmers, 1980-8: comparison of PMR and SMR approaches. Am 7 Epidemiol 1995;141:878-82.

35 Zhou C, Roseman JM. Agricultural injuries among a population-based sample of farm operators in Alabama. $A m \mathcal{F}$ lation-based sample of farm

36 Waller JA. Injuries to farmers and farm families in a dairy state. F Occup Med 1992;34:414-21.

37 Pratt DS, Marvel LH, Darrow D, Stallones L, May JJ, Jenkins $P$. The dangers of dairy farming: the injury experience of 600 workers followed for two years. $\mathrm{Am} \mathcal{F}$ Ind Med 1992;21:637-50.

38 Salminen S, Saari J, Saarela KL, Räsänen T. Organizational factors influencing serious occupationa accidents. Scand f Work Environ Health 1993;19: 352-7.

39 Stallones L. Education, equipment modification and injury control among farm workers in Kentucky. fournal of control among farm workers in Kentuck
Occupational Accidents 1989:10;293-303.

40 Stallones $L$. Surveillance of fatal and non-fatal farm injuries in Kentucky. Am $\mathcal{F}$ Ind Med 1990;18:223-34.

41 Charlton J, Kelly S, Dunnell K, Evans B, Jenkins R Suicide deaths in England and Wales: trends in factors associated with suicide deaths. Population Trends 1993, 71:34-42.

42 Stallones L. Suicide mortality among Kentucky farmers. Suicide Life Threat Behav 1990;20:156-63

43 Stallones L, Cook M. Suicide rates in Colorado from 1980 to 1989: Metropolitan, nonmetropolitan and farm comparisons. Fournal of Rural Health 1992;8:139-42.

44 Pickett W, Davidson JR, Brison RJ. Suicides on Ontario farms. Can F Public Health 1993;84:226-30.

45 International Agency for Research on Cancer. Solar and ultraviolet radiation, LARC monographs on the evaluation of ultraviolet radiation, LARC monographs on the evaluation of

46 Swerdlow AJ. Incidence of malignant melanoma of the skin in England and Wales and its relationship to sunshine. BMF 1979;2:1324-7.

47 Swerdlow A, dos Santos Silva I. Atlas of cancer incidence in England and Wales 1968-85. Oxford: Oxford Medica Publications, 1993.

48 Cartwright $R$, McNally $R$, Staines $A$. The increasing incidence of non-Hodgkin's lymphoma (NHL): the possible role of sunlight. Leuk Lymphoma 1994;14:387-94.

49 Mueller N. Another view of the epidemiology of nonHodgkin's lymphoma. Oncology 1994;8:83.

50 Hartge P, Devesa SS, Grauman D, Fears TR, Fraumeni JF. Non-Hodgkin's lymphoma and sunlight. $f$ Natl JF. Non-Hodgkin's lympho

51 International Agency for Research on Cancer. Alcohol drinking, LARC monographs on the evaluation of carcinogenic risks to humans. Vol 44. Lyon: IARC, 1988

52 Tuyns AJ, Péquignot G, Abbatucci JS. Oesophageal cancer and alcohol consumption: importance of type of beverage. Int $\mathcal{F}$ Cancer 1979;23:443-7 